\title{
EXPLORING ENGLISH TEACHERS' STRATEGIES IN COPING WITH STUDENTS' MISBEHAVIOR IN LEARNING ENGLISH: A CASE STUDY AT A PRIVATE VOCATIONAL HIGH SCHOOL IN PEKANBARU
}

\author{
Hemniati \\ State Islamic University Sultan Syarif Kasim Riau \\ hemniati11@gmail.com \\ Abdul Hadi \\ State Islamic University Sultan Syarif Kasim Riau \\ abdul.hadi@uin-suska.ac.id \\ Promadi \\ State Islamic University Sultan Syarif Kasim Riau \\ promadi@uin-suska.ac.id
}

\begin{abstract}
Abstrak
Penelitian ini bertujuan untuk mengeksplorasi strategi guru bahasa Inggris dalam mengatasi perilaku menyimpang siswa dalam pembelajaran bahasa Inggris di SMK Swasta Pekanbaru. Penelitian ini menggunakan pendekatan kualitatif. Partisipan penelitian ini melibatkan dua guru bahasa Inggris dan 85 siswa kelas sepuluh. Teknik pengumpulan data yang digunakan dalam penelitian ini adalah observasi dan wawancara. Hasil penelitian ini menemukan enam jenis strategi guru yang digunakan oleh guru bahasa Inggris dalam mengatasi perilaku menyimpang siswa di kelas. Mereka; (1) Strategi verbal, (2) Teguran dan hukuman, (3) Strategi non-verbal, (4) Mencegah perilaku buruk, (5) Mengatasi konfrontasi, dan (6) Pelayanan pastoral. Strategi verbal dan teguran dan hukuman yang digunakan oleh guru bahasa Inggris sering diam di dalam kelas. Namun, strategi verbal adalah strategi yang paling sering digunakan oleh guru bahasa Inggris dalam mengatasi perilaku siswa yang salah dalam pelajaran bahasa Inggris di SMK TARUNA SATRIA Pekanbaru.
\end{abstract}

Kata kunci: Strategi Guru, Perilaku Buruk Siswa, Pembelajaran Bahasa Inggris 


\section{Abstract}

This research aims to exploring English teachers' strategies in coping with students' misbehavior in learning English at a Private Vocational High School Pekanbaru. The study employed qualitative approach. The participants of this study involves two English teachers and 85 students of ten grade class. The data collecting technique used in this study were observation and interview. The result of this research discover six types of teachers' strategies used by English teacher in coping with students' misbehavior in the classroom. They were; (1) Verbal strategies, (2) Reprimand and punishment, (3) Non-verbal strategies, (4) Pre-empting misbehavior, (5) Dealing with confrontation, and (6) Pastoral care. Verbal strategies and reprimand and punishment used by English teacher quiet often in the classroom. However, verbal strategies is the most frequently strategies used by English teachers in coping with students' misbehavior in English lessons at SMK TARUNA SATRIA Pekanbaru.

Keywords: Teachers' strategies, students' misbehavior, English learning

\section{Introduction}

Salviana, Muslem and Daud stated that "Teaching and learning are important parts of human life" ${ }^{\prime}$. The teacher does not only teach the students but also educate them. The importance of teachers' role in teaching and learning process was expressed by Rusman, she stated that the teachers should know about students' development, in order that it is important for the teachers to pay attention to all the students. She also emphasized the importance of teachers' communication skill in order to avoid miscommunication in the classroom during teaching and learning process. ${ }^{2}$

There are several definitions of students' misbehavior in the literature. Some of educators prefer to say it inappropriate behavior, disruptive behavior and maladaptive behavior. It is depend on the educators' idiosyncrasies ${ }^{3}$. Vedadri point out "disruptive behavior is described as when a child is not cooperative and preventing themselves and other children in the class from performing the work given by the teachers" ${ }^{4}$. Another

\footnotetext{
${ }^{1}$ Salviana, Muslem, A, and Daud, B., (2018). English student teachers' constraints during their teaching internship programs with the english department of fkip at unsyiah in aceh. Syah Kala University, Banda Aceh.

${ }^{2}$ Rusman, P. Y. F, (2017). A descriptive study of the teacher's technique on controlling the students' misbehavior in smpn 1 sukasada. International Journal of Language and Literature. Vol.1, No.1, February 2017.

3 Charles, C. M. (2007). Preventing misbehavior: Taking proactive steps to prevent the occurrence of misbehavior in the classroom. Retrieved from http:// ptgmedia.pearsoncmg.com/imprint_dowloads/mer rill_profesional/images/0205510701Charles_ch02_18-33.pdf

${ }^{4}$ Veradri, A., (2020). Disruptive Behavior Managing the Challenge and Issues-a Case Study. International Journal of Psychosocial Rehabilitation • May 2020
} 
explanation that Sun and Shek define classroom misconduct is behaviors that disrupt classroom order and cause trouble to the teachers, such as making nonverbal noise, disobedience, talking nonsense, laziness/slowness, unpunctuality, hiding others, physical aggression, untidy, not in the seat, and verbal abuse..$^{5}$ In the most general sense, Kyriacou defines "pupil misbehavior refers to any behavior by a pupil that undermines the teacher's ability to establish and maintains effective learning experiences in the classroom" ${ }^{\text {. From }}$ the definitions above, it can be concluded that students' misbehavior is any kind of psychologically and physically behavior which interfere classroom atmosphere and disrupt the process of achieving teaching and learning goals.

"Teachers can encounter lots of different types of problematic behaviors in a classroom setting from students' distraction of attention to hitting other students",7 Cimen and Cepik-Kiris. According to Kyriacou, "Pupil misbehaviour can range from simple noncompliance (e.g. not paying attention) to overt disruptive behaviour (e.g. throwing a missile across the room)" 8. While, Meyers in Bayhan and Dalgic classified students' misbehavior as being overt and covert. Overt refers to open and observable behaviors like students talking during class, using cell phone, eating or drinking, while covert refers to passive behavior like sleeping during class, coming late, leaving class early, acting bored and disengaged. ${ }^{9}$

Wulandari stated that the causes of students' misbehavior are not something that uncertain. The causes can be identified by the teachers. Students' misbehavior can be caused by many reasons. The student perform a lot of activities in the classroom. Those activities can be change or constant in every day since every student has different background of live and environment. Students' behavior can influence by a number of factors such as environment, friends and their family life ${ }^{10}$. Harmer cited in Wedhanti and Sasih claimed that there are six factors why problem occur by the students such as family,

5 Sun, R. C.F. \& Shek, D. T.L. (2012). Student Classroom Misbehavior: An Exploratory Study Based on Teachers'Perceptions. Hong Kong. The Scientific World Journal.

${ }^{6}$ Kyriacou, C. (2009). Effective teaching in schools theory and practice (3rd ed). United Kingdom: Stanley Thornes. (p.121).

7 Cimen, S. S., and Cepik-Kiris, H., (2015). Pre-service efl teachers' perceptions of and strategies in dealing with misbehavior. Educational Research Association The International Journal of Educational Researchers 2015, 6 (3) : 43-49 ISSN: 1308-9501. (p.44).

${ }^{8}$ Kyriacou, C. (2009). Effective teaching in schools theory and practice (3rd ed). United Kingdom: Stanley Thornes. (p.121).

${ }^{9}$ Bayhan, G., \& Dalgic, G, (2014). Students' misbehavior, meta-analysis, classroom management. Cypriot journal of educational sciences, 9(2), 101-116.

${ }^{10}$ Wulandari, L, (2011). Teacher's Strategies In Dealing With The Students' Disruptive Behavior In Teaching And Learning Process At The Eleventh Grade Of Smkn11 Surabaya. Thesis. 
education, self-esteem, a lack of respect from teacher or peers, boredom and external factors. ${ }^{11}$

A number of studies have been conducted related to teachers' strategies in dealing with students' misbehavior in the classroom. In Indonesia context, Rusman has conducted the study about teacher technique on controlling students' misbehavior in SMPN 1 Sukasada. The most frequent misbehavior conducted by the students were disruption and needless talk, and the most strategies used by the teachers are reprimand and pre-empting pupil misbehavior. ${ }^{12}$ A study about assessment of students' misbehavior and coping strategies in Shashemene Secondary School has been conducted by Mekuria. To deal with those students' misbehavior, the school applied MoE guideline and warning is found as commonly applied coping strategies in this study. Furthermore, meaningful engagement of stakeholders, assignment of professional for counseling, strong collaboration with parents and corporal punishment were seldom implemented as penalty against student misbehavior. 13

Based on the discussion of previous studies on students' classroom misbehavior, most of them focus on the types of the misbehavior. Moreover, in Indonesia there only a few research of students' misbehavior conducted in vocational high school context. This study was conducted considering the importance of teachers' strategies in dealing with students' misbehavior in vocational high school context.

\section{Research Methods}

In answering research question in this study, the writer used qualitative approach especially case study method. As a case study, the data in this study collected from various sources and the result of this study applied only to the cases investigated. To answer the research question, the writer used observation and interview to collect the data.

The research was conducted at Private Vocational High School Taruna Satria Pekanbaru. The participants of this study were two English teachers and 85 students of ten grade at SMK TARUNA SATRIA Pekanbaru. The data analyzed with the steps of

\footnotetext{
${ }^{11}$ Wedhanti, N.K, and Sasih, L.L, (2017). An analysis of classroom students' misbehaviors in mechanical engineering department class of grade xi in smk negeri 3 singaraja. Vol.1, No.1, February 2017. (p.92).

${ }^{12}$ Rusman, P. Y. F, (2017). A descriptive study of the teacher's technique on controlling the students' misbehavior in smpn 1 sukasada. International Journal of Language and Literature. Vol.1, No.1, February 2017.

${ }^{13}$ Mekuria, A., T. (2012). Assessment of students' misbehavior and coping strategies (in the case of shashemene secondary school). Addis Ababa University.
} 
transcribing, coding, categorizing, interpreting, and validating the finding by using member checking.

\section{Finding and discussion}

These point present the finding of teachers' strategies in coping with students' misbehavior in learning English. The first part is the answer to the first research question about the strategies used by English teacher in coping with students' misbehavior. Then, the second part is the answer to the second research question about why the teachers choose those strategies. The last part is the answer of the third research question about how did students' behavior after the English teachers apply the strategies.

\section{Strategies used by English teacher to cope with students' misbehavior in learning English}

The researcher only focuses on the strategies used by the English teacher in the classroom. As the result, the researcher found out several strategies used by the English teachers in coping with students' misbehavior during teaching and learning process. Those strategies will be explained in the following:

\section{Verbal strategies}

Based on the result of the data analysis, verbal strategies are one of the most frequently strategy used by the teachers to cope with students' misbehavior in the classroom. Verbal strategies found in this study are calling on students' name, waking the students up and talking to students. The teachers also stated the same strategies in an interview session. As the teacher A (Mam E) said:

"When the other students focus to the lesson, there were students who talk to their friends. I usually reprimand them and called their name one by one and ask them a question so, they can stop talking". (Interview with teacher A 18/2/2021)

Furthermore, the teacher B (Miss S) also stated the same statement. She stated that:

"...when I was explaining the lesson in front of the class, I sometimes called their name in order to make them stop talking. I asked the students who were sleeping in the classroom to wash their face so they can concentrate to the lesson." (Interview with teacher B 18/2/2021)

From the statement above, the teacher tends to use verbal strategies to deal with students' misbehavior found in the classroom. The use of this strategy was proven by the observation data found in the field. The researcher found verbal strategies used by English teacher through all of the observation process. The types of verbal strategies found in this study were (a) called on students' name, (b) wake the students up and (c) talking to students. 


\section{Reprimand and Punishment}

The second strategies used by the teacher in coping with students' misbehavior found in this study are reprimand and punishment. This strategy is the second most frequent strategies used by English teachers in coping with students' misbehavior in the classroom. English teachers tend to give caution to the students first. If they did not stop doing misbehavior, the teacher will give them such a punishment. The punishment given to the students might be different according to the types of students' misbehavior. This is proven by the teacher when they were interviewed. Teacher A (Mam E) stated that:

"Exactly, there will be a punishment. They are not allowed to attend the class. In order to let them know the consequence of what they have done". (Interview with Teacher A 18/2/2021)

Teacher B (Miss S) also used reprimand and punishment in coping with students' misbehavior in the classroom. Similarly, Miss $\mathrm{S}$ also said that:

"I give them reprimand. I will take their mobile phone if they still play it in the classroom after I give them reprimand three times. I will give their phone to their classroom teacher or they have to make an agreement letter." (Interview with teacher B 18/2/2021)

If the students still do misbehave in the classroom, the teacher also gives them punishment, just like Teacher B (Miss S) said:

"Hmm, I give them punishment to the students who did not bring their dictionary in English subject. They have to do push up or squad jump. If they cross the line, they have to make an agreement letter and approved by their teacher". (Interview with teacher B 18/2/2021)

\section{Non-verbal strategies}

The third strategies used by the teacher in coping with students' misbehavior found in this study are non-verbal strategies. Non-verbal strategies include interventions such as using eye-contact, using gestures, approaching to students, etc. Non-verbal strategies found in this study was using eye contact and using media.

The used of this non-verbal strategies proven by the data of observation. Based on the data presented in table 4.2, this strategy found in the fifth classroom observation obtained on February 17th, 2021 in X CNE 3. The teacher used eye contact to deal with noisy students. The researcher saw the class was so crowded and the students were noisy. The teacher stands up in front of the class and just keep quiet. She looked at her students and still quiet. Finally, some students realized that their teacher wants them to keep silent and they asked their friend to keep quiet. 
During the sixth classroom observation on February $18^{\text {th }} 2021$ in the X CNE 2 class, the teacher used media in teaching and learning process. The aim of this strategy is to engage students' attention and interest during teaching and learning process.

\section{Pre-empting Misbehavior}

The next strategies used by the teacher in dealing with students' misbehavior are pre-empting misbehavior. This strategy used to prevent misbehavior by using vigilance and action. It means that the teacher monitoring students' misbehavior and their learning activities in the classroom.

This strategy found in the fifth and sixth classroom observation. The teachers walked around the classroom to check students' progress and to make sure that the students follow the lesson. As the teacher (Miss S) said in the interview session:

"...I walked around the class to control the students, because there are various number of students. I cannot see the students on the back seat, so I usually walked to the back side of the classroom"... (Interview with teacher $B$ 18/2/2021)

On the other hand, the teacher (Mam E) has a different strategy to prevent students' misbehavior in the classroom. She explained that:

"...Before the class began, I like to check their phone first. I asked all of them to put their phone on the table. Then, I took their phone one by one and put them on my table. I took their phone, so they can concentrate with the lesson. After their phone was taken, there will be a difference in their focus and concentration". (Interview with teacher A 18/2/2021)

Based on teacher A stated above, the teacher choose to prevent students' misbehavior before the class begins. She took the phone which considered as the thing that might be the trigger for the students to do misbehave in the classroom during teaching and learning process.

\section{Pastoral Care}

This strategy helps the teacher to know the reason why the students do misbehave, what happened with the students and maybe there are any problems faced by the students which require attention from the teacher. The English teacher stated that she used pastoral care as her strategy in coping with students' misbehavior in an interview session. She (Mam E) stated that:

"Hmm, approach. I tried to figure out the reason why the student do that? Like that. If they did not understand with the language, at that time he did not understand with the language. So, I decided to return this case to the school regulation". (Interview with teacher A 18/2/2021) 
Moreover, the teacher did not apply this strategy directly to the students. They tend to ask their classroom teacher first, so the teacher will get the information she needed. As the teacher A (Mam E) said:

"Hmmm, I return this case to the classroom teacher. I tried to figure out who is their classroom teacher and what happened with the student? Then we may know the information about the students, their parents and their family's background. So, when I found students who did misbehave, I will confirm to their classroom teacher before return the cases to the school authority". (Interview with teacher A 18/2/2021)

6. Dealing with Confrontation

One of the strategy that teacher use is dealing with confrontation. This strategy's aims to reduce the emotional confrontation that might occur in the classroom between the teacher and the students. Teacher A (Mam E) argued that:

"'....second, when we found the students were lack of interest, we have to be able to herd them and make them focus on learning. Sometimes, we need to build an interesting classroom situation. Sometimes, as a classroom teacher, we need to build a good relationship with students, because the students usually tell their problem to us as a classroom teacher. More or less we know what happened with them. So, we can got them with a little bit of jokes and humors related to their problems to make them having fun and become more active in the class". (Interview with teacher A 18/2/2021)

The teacher tried to build a good relationship with the students in order to make them feel comfortable to tell whatever they feel and to build their willingness in learning English. Automatically, the students will listen to the teacher and they will not do misbehavior during teaching and learning process.

\section{The reason why the teacher used those strategies in coping with students' misbehavior}

There are a lot of strategies that teacher can use in dealing with students' misbehavior. But, choosing the appropriate one is the most important thing to do. Every teacher has their own reason in choosing the strategies depend on the students' condition and classroom situation they faced in teaching and learning process. Thus, the researcher makes this point as the second research question which aim to explore the reasons why the teacher used those strategies in coping with students' misbehavior in the classroom.

Based on the result of this study, the researcher has revealed several strategies used by English teachers. The first strategy is verbal strategies. Verbal strategies are the most 
frequently strategies used by English teachers in the classroom. Verbal strategies used by English teacher are calling on students' name, wake the students up and talking to the students. The teacher used this strategies because it was the fastest way to stop students' misbehavior immediately.

The second strategy is reprimand and punishment. Both of English teachers used this strategy in coping with students' misbehavior. They conveyed that this strategy is effective to deal with students' misbehavior since the students will be afraid when the teacher give them punishment. The teacher also stated that the aim of this strategy is to give deterrent effect, so the students will not repeat the same misbehavior and in order to make them focus on teaching and learning process.

The third strategy is non-verbal strategies. This strategy used by English teachers when the class becomes so crowd and the students being noisy. The teachers used eye contact to give the students such a message to keep silence and focus in teaching and learning process. The teacher choose this strategy because sometime they realize that the students' voice is too loud and using eyes contact is the effective way to handle the students' misbehavior.

The fourth strategy is pre-empting misbehavior. The teachers used this strategy because there are a various number of students in the class. The teachers cannot control them from their table. They should walk around the classroom to check the students one by one. As the teacher said:

“...I walked around the class to control the students, because there are various number of students. I cannot see the students on the back seat, so I usually walked to the back side of the classroom"... (Interview with teacher $B$ 18/2/2021)

Besides that, the teachers also use this strategy because they want the students to focus to the lesson, so the teachers choose to prevent misbehavior by relieving the causes of it. As the teachers said:

"...Before the class began, I like to check their phone first. I asked all of them to put their phone on the table. Then, I took their phone one by one and put them on my table. I took their phone, so they can concentrate with the lesson. After their phone was taken, there will be a difference in their focus and concentration". (Interview with teacher A 18/2/2021)

The fifth strategy used by English teachers is dealing with confrontation. The teachers used this strategy because they want to avoid the confrontation which might be occur in the classroom. The teachers sometimes give a little bit of humors while learning English to engage students' interest, focus and willingness in learning English. As the teacher said: 
"Hmm, approach. I tried to figure out the reason why the student do that? Like that. If they did not understand the language, at that time he did not understand with my language. So, I decided to return this case to the school regulation". (Interview with teacher A 18/2/2021)

The last strategy is pastoral care. The teachers used this strategy because they think that it is necessary to keep a good student-teachers relationship. They may understand each other and the teacher will be able to choose an appropriate strategy and treatment for the students.

\section{Students' misbehavior after the English teachers apply the strategies}

In this study, the researcher found that the development of students' behavior after English teacher apply the strategies was different in each class. This is can be seen from students' misbehavior which found in every meeting. Based on the result of an interview with two English teachers, generally, both of them argued there are a positive development of students' behavior after they applied those strategies. Like teacher A (Mam E) stated:

"More or less, they tell us about their problem. They may assume us as their friend and their teacher in the right place and the right time. As a teacher, we need to limit ourselves. We have to limit what to know and how deep we need to know about the students. After we apply the strategies, the students can realize when they treat us like a teacher and a friend, and I think it is working well. There are a positive changes in the development of their behavior". (Interview with teacher A 18/2/2021)

Similarly, teacher B (Miss S) also stated the same:

"I saw that they become more discipline and they make a progress than before. I also saw there is a positive development from time to time and they get used to the rules. I hope they may become more discipline in the future". (Interview with teacher B 18/2/2021)

However, when the researcher did the classroom observation, the researcher found different results among the classes. The data presented in the table below:

Table 4.3

Students' misbehavior after English teachers apply the strategies

\begin{tabular}{|c|c|c|c|c|c|c|}
\hline \multirow{2}{*}{ Classes } & \multicolumn{6}{|c|}{ Students' Misbehavior } \\
\cline { 2 - 7 } & $\mathbf{1}$ & $\mathbf{2}$ & $\mathbf{3}$ & $\mathbf{4}$ & $\mathbf{5}$ & $\mathbf{6}$ \\
\hline X CNE 3 & $\begin{array}{l}\text { 1. Did not } \\
\text { bring } \\
\text { the }\end{array}$ & $\begin{array}{c}\text { 1. Using } \\
\text { mobile } \\
\text { phone }\end{array}$ & $\begin{array}{c}\text { 1. Talking } \\
\text { with } \\
\text { friends }\end{array}$ & $\begin{array}{c}\text { 1. Using } \\
\text { mobile } \\
\text { phone }\end{array}$ & \\
\hline
\end{tabular}




\begin{tabular}{|c|c|c|c|c|c|c|}
\hline & \begin{tabular}{|l} 
diction \\
ary \\
2. Talking \\
with \\
friends \\
3. Day \\
dreami \\
ng \\
4. Sleepin \\
g
\end{tabular} & \begin{tabular}{|l} 
in the \\
classro \\
om \\
2.
\end{tabular} & & 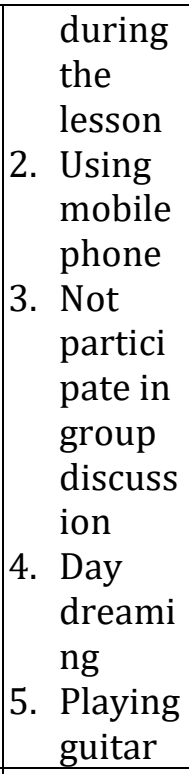 & $\begin{array}{l}\text { 2. Sleeping } \\
\text { 3. Did not } \\
\text { bring } \\
\text { the } \\
\text { dictiona } \\
\text { ry } \\
\text { 4. Being } \\
\text { noisy } \\
\text { 5. Not } \\
\text { paying } \\
\text { attentio } \\
\text { n }\end{array}$ & \\
\hline $\begin{array}{c}\mathrm{X} \\
\text { Accounting }\end{array}$ & & & $\begin{array}{l}\text { 1.Using } \\
\text { mobile } \\
\text { phone } \\
\text { 2. Talking } \\
\text { with } \\
\text { friends }\end{array}$ & & & \\
\hline X CNE 2 & & & & & & $\begin{array}{l}\text { 1. Using } \\
\text { mobile } \\
\text { phone } \\
\text { 2. Talking } \\
\text { with } \\
\text { friends }\end{array}$ \\
\hline
\end{tabular}

The table 4.3 shows the types of students' misbehavior found in each class through classroom observation. The researcher obtained a classroom observation six times. Based on the data presented in the table 4.3 above, the first classroom observation conducted in the X CNE 3 class. There are four types of students' misbehavior found in this class. As for students' misbehavior occur in the classroom in the first classroom observation were did not bring the dictionary, talking with their friends, day dreaming and sleeping. The teacher used several strategies to deal with those misbehavior, but the students still do the same misbehavior in the classroom.

In the second classroom observation, the researcher found the students still do the same misbehavior. The students keep talking with their friend in the process of teaching and learning English. Moreover, the researcher found the new types of students' misbehavior. They were using mobile phones in the classroom and the students being noisy when the teacher explain the lesson. 
Furthermore, in the next classroom observation until the last, there was no change in students' misbehavior in the X CNE 3 class. The students keep doing their misbehavior, even though the teacher have used some strategies in coping with it. The researcher still found the same misbehavior as previous meeting such as talking with friends, using mobile phone, and day dreaming. Moreover, the other types of students' misbehavior also found in this class. They did not participate in group discussion and playing guitar.

In the other hand, there were only two kinds of students' misbehavior found in X CNE 2 class and X Accounting class in classroom observation. They are using mobile phones and talking with friends. The students in X CNE 2 class and X Accounting class give a positive response to teachers' strategies. After English teacher use the strategies, the students stop doing misbehavior immediately. They focus to the lessons and become more active in the classroom.

From the explanation above, it can conclude that the students respond to English teachers' strategies differently. The students in X CNE 3 class tend to ignore teachers' strategies when they do misbehavior in the classroom. The students repeat what they do in the classroom and they also do the other type of misbehavior in the next meeting. Meanwhile, the students in X CNE 2 and Accounting class tend to respond teacher's strategies positively. They stop doing misbehavior when the teacher gives them such a reprimand or punishment. They do not repeat their misbehavior until the end of the class. They become focused and pay attention to the teacher.

\section{Discussion}

This study showed that there are six types of strategies used by English teacher in coping with students' misbehavior in learning English. Verbal strategies and reprimand and punishment were the most frequent strategies used by English teachers. The finding of this study in line with strategies suggested by Kyriacou. He suggested four strategies in coping with students' misbehavior; pre-empting misbehavior, reprimand and punishment, dealing with confrontation and pastoral care. ${ }^{14}$ Based on the research finding, the researcher found that all of the strategies used by English teachers in coping with students' misbehavior in the classroom at SMK TARUNA SATRIA Pekanbaru. Verbal and non-verbal strategies also found in this study. Similarly, Ningsih, Putra \& Ramendra found that the teachers also reminded the students when they misbehave against the classroom rules. Based on the analysis of observation data, all of this verbal strategies, mostly applied by English teachers to control students' misbehavior occur in the classroom in every

\footnotetext{
${ }^{14}$ Kyriacou, C. (2009). Effective teaching in schools theory and practice (3rd ed). United Kingdom: Stanley Thornes.
} 
meeting. ${ }^{15}$ This finding is in line with Weinstein's strategies categorization cited in Cimen and Cepik-Kiris. In dealing with students' misbehavior, Weinstein categorized teachers' intervention strategies into two groups: verbal strategies and non-verbal strategies. ${ }^{16}$

Based on the result of an interview with two English teachers, they stated their reason why they used those strategies and also their consideration in choosing those strategies. Teacher A (Mam E) explained that knowing the reason why students do misbehave is necessary. It is important to question what happened with the students and why they behave like that. After knowing the factor, the teacher may decide the best strategies to cope with the problems. Similarly, Kyriacou stated that "How you develop your approach to deal with pupil misbehavior is likely to be influenced by your beliefs about how best to address the underlying causes of pupil behavior"17. Furthermore, Yuan and Che also stated that the teachers have to understand the sources before dealing with students' misbehavior, since misbehavior is the result from a large range of causes came from the environment such as the students themselves, classroom, school, community and the whole society. ${ }^{18}$

\section{Conclusion}

Based on the findings and the discussion, the researcher draws the answer of the research questions related to English teachers' strategies in coping with students' misbehavior in learning English. In general, the strategies used by English teachers in coping with students' misbehavior at SMK TARUNA SATRIA PEKANBARU are similar to the strategies which are contained in the literature review. There are six types of strategies found in this study, they are: verbal strategies, reprimand and punishment, non-verbal strategies, pre-empting misbehavior, pastoral care and dealing with confrontation. Verbal strategies and reprimand and punishment used by English teacher quiet often in the classroom. However, verbal strategies is the most frequently strategies used by English

${ }^{15}$ Ningsih, Putra \& Ramendra, (2019). Teacher's coping style strategy with misbehaving students. Lingua Scientia. P-ISSN: 0854 - 9125 E-ISSN: 2599 - 2678 Vol. 26 No. 1, June 2019

${ }^{16}$ Cimen, S. S., and Cepik-Kiris, H., (2015). Pre-service efl teachers' perceptions of and strategies in dealing with misbehavior. Educational Research Association The International Journal of Educational Researchers 2015, 6 (3) : 43-49 ISSN: 1308-9501.

${ }^{17}$ Kyriacou, C. (2009). Effective teaching in schools theory and practice (3rd ed). United Kingdom: Stanley Thornes. (p.125)

${ }^{18}$ Yuan, $\mathrm{X}$ and Che, L. (2012). How to deal with student misbehvaior in the classroom? journal of educational and developmental psychology. Vol.2, pp. 143-150. 
teachers in coping with students' misbehavior in English lessons at SMK TARUNA SATRIA Pekanbaru.

Each of English teacher has their own consideration in determining the strategies they used in coping with students' misbehavior in the classroom. The strategies used by English teachers was depended on the type of students' misbehavior found in the classroom. Furthermore, the teachers used verbal strategies because the teachers wanted the students to stop doing misbehavior immediately. English teachers also used reprimand and punishment strategies because they wanted to give deterrent effect to the students, so that the students will not do their misbehavior in the future. Moreover, the teachers used non-verbal strategies to deal with students' misbehavior. The teachers choose to apply this strategy because they cannot handle the students because the classroom is very noisy. Asking the students to stop being noisy by using teachers' voice will not make any change, so the teachers decide to use verbal strategy such as eye contact. The next teachers' strategy is pre-empting strategies. The teachers used this strategy in order to prevent students' misbehavior possibility in the classroom. Moreover, the teacher also used dealing with confrontation strategies because it is necessarily needed to build an interesting classroom situation. The last strategies used by English teacher is pastoral care. Pastoral care used by English teachers in order to build a good student-teachers relationship, so the teachers may choose the appropriate treatment for the students who often do misbehavior in the classroom.

In this study, the researcher found that the development of students' behavior after English teacher apply the strategies was different in each class. The students in X CNE 3 class tend to ignore teachers' strategies. The students' misbehavior in this class was not decreased after the teacher apply the strategies. The students tend to recurring their misbehavior even though the teacher has apply her strategies to stop them.. Meanwhile, the students in the X CNE 2 and X Accounting class response teachers' strategies positively. The students show a change in their behavior after the teacher apply the strategies.

\section{References}

Bayhan, G., \& Dalgic, G, (2014). Students' misbehavior, meta-analysis, classroom management. Cypriot journal of educational sciences, 9(2), 101-116.

Charles, C. M. (2007). Preventing misbehavior: Taking proactive steps to prevent the occurrence of misbehavior in the classroom. Retrieved from http:// ptgmedia.pearsoncmg.com/imprint_dowloads/mer rill_profesional/images/0205510701Charles_ch02_18-33.pdf 
Cimen, S. S., and Cepik-Kiris, H., (2015). Pre-service efl teachers' perceptions of and strategies in dealing with misbehavior. Educational Research Association The International Journal of Educational Researchers 2015, 6 (3) : 43-49 ISSN: 1308-9501.

Kyriacou, C. (2009). Effective teaching in schools theory and practice (3rd ed). United Kingdom: Stanley Thornes.

Mekuria, A., T. (2012). Assessment of students' misbehavior and coping strategies (in the case of shashemene secondary school). Addis Ababa University.

Ningsih, Putra \& Ramendra, (2019). Teacher's coping style strategy with misbehaving students. Lingua Scientia. P-ISSN: 0854 - 9125 E-ISSN: 2599 - 2678 Vol. 26 No. 1, June 2019

Rusman, P. Y. F, (2017). A descriptive study of the teacher's technique on controlling the students' misbehavior in smpn 1 sukasada. International Journal of Language and Literature. Vol.1, No.1, February 2017.

Salviana, Muslem, A, and Daud, B., (2018). English student teachers' constraints during their teaching internship programs with the english department of fkip at unsyiah in aceh. Syah Kala University, Banda Aceh.

Sun, R. C.F. \& Shek, D. T.L. (2012). Student Classroom Misbehavior: An Exploratory Study Based on Teachers'Perceptions. Hong Kong. The Scientific World Journal.

Veradri, A., (2020). Disruptive Behavior Managing the Challenge and Issues-a Case Study. International Journal of Psychosocial Rehabilitation • May 2020

Wedhanti, N.K, and Sasih, L.L, (2017). An analysis of classroom students' misbehaviors in mechanical engineering department class of grade xi in smk negeri 3 singaraja. Vol.1, No.1, February 2017.

Wulandari, L, (2011). Teacher's Strategies In Dealing With The Students' Disruptive Behavior In Teaching And Learning Process At The Eleventh Grade Of Smkn11 Surabaya. Thesis.

Yuan, $\mathrm{X}$ and Che, L. (2012). How to deal with student misbehvaior in the classroom? journal of educational and developmental psychology. Vol.2, pp. 143-150. 